\title{
Administration and the Courts
}

\author{
By JAMES HaRT
}

$\mathrm{T}$ THE relation of the courts to bureaucracy cuts across every branch of American law: constitutional and statutory law, criminal and civil law, the common law and equity. It is accordingly so complex, and so involved in technical distinctions, that no attempt will here be made to explore its details. The present purpose is rather to capture, if that be possible, a few glimpses of its broad significance.

The clue to that significance is to be sought in the role of the judiciary in our constitutional system. The Constitution is formally the source of a legal order or regime of law; and this regime of law can be made effective in action only if, its application to any particular situation being disputed, there exists an independent third party which is empowered authoritatively to settle the dispute when, but only when, it is appealed to by either of the disputing parties.

Such independent third parties are the courts. Their third-party character is necessary to protect one disputant from having the other impose a settlement by acting as judge in his own cause. It is underlined by the fact that they may not take the initiative, but must sit passively until some plaintiff initiates before them some case against some defendant. Its bulwark is their independence, which is secured by such means as the tenure of judges and their immunity from criminal and tort liability for the manner in which they exercise their judicial powers.

The application of the law to a particular situation includes determining the facts of that situation by following the applicable rules of law. These rules may prescribe that the facts shall be those agreed upon by the parties to the dispute. They may establish as the facts those well pleaded by one of those parties and admitted upon demurrer by the other. They may provide that the facts shall be those found by judge or jury upon the basis of the evidence offered and allowed, including the testimony of witnesses for both sides, in accordance with the law of evidence. They may also provide that the facts shall be those found, upon the basis of notice and a hearing, by a quasi-judicial tribunal, provided those facts are upon challenge found by the court to be supported by substantial evidence in the light of the whole record or such portions thereof as may be cited to the court.

\section{The Repeated Pattern}

In all branches of the law, and regardless of whether the government or an administrative official or agency is party plaintiff or party defendant, the role of the courts is in essence the same. The central pattern always consists of a plaintiff, a defendant, and a court as the independent third party settling the dispute by applying the law to the legally determined facts.

In a criminal case, the role of the plaintiff falls primarily to the prosecuting attorney, and the defendant is always the accused. But the role of the court is the same, whether the accused is a storekeeper indicted for murdering his wife or an official indicted for a misdemeanor in office.

In a tort case, the plaintiff may be the owner of a horse, and the defendant a neighbor who allegedly has injured 
the horse out of spite. The defendant may, however, be a health officer who has killed the horse without notice on the ground that it had the glanders.

In the law of contracts, the plaintiff may be a merchant who is seeking to collect from the defendant on goods delivered. That defendant may be an ordinary customer; but he may be an official who, in ordering registration supplies, acted ultra vires because the county was not subject to the registration laws, but who is alleged to have used apt words to bind himself personally. This is not to say that the law is the same for a contracting agent of government as for the agent of a private individual or firm. It is to say that the role of the court is in principle the same in both instances.

In equity, the plaintiff or complainant may be the owner of water-front real property who seeks to have the defendant or respondent enjoined from threatened action which he claims will work him irreparable injury. The defendant may be a boat company whose planned wharf the plaintiff alleges will obstruct entrance to his property; but he may be the Secretary of Defense, whose planned harbor improvements the plaintiff claims are in excess of his statutory authority.

Or take two of the extraordinary common-law writs. The plaintiff or relator may seek a mandamus against a municipal official to compel him to issue a license to engage in the hardware business, on the ground that under a city ordinance the only condition for the issuance of such a license is the payment of a fee which has been tendered and refused, and that it is therefore the ministerial duty of the official to accept the fee and issue the license. Or the plaintiff or applicant may seek to have a writ of habeas corpus issued to the immigration officer who holds him in custody under a warrant for his ar- rest and deportation as an alien illegally in the United States, when the plaintiff claims to be a foreign-born son of a native-born citizen.

Still again, the parties may be a manufacturing company and the National Labor Relations Board; but either may be plaintiff or defendant. For, the Board having served upon the company an order to cease and desist from specified unfair labor practices, under the statutory review provisions of the governing statute the company may apply to a national Court of Appeals for review, and the Board may apply to the same court for enforcement, of the order.

In the illustration last cited, whichever party moves first, the function of the court is the same: to affirm, modify, or set aside the order according to whether the Board's findings as to the facts are or are not supported by substantial evidence, its procedure has or has not been lawful, and its order is or is not in all respects of a legally permissible scope. The court's duty is no more to throttle the Board than it is to enforce its order without question, no more to curb the Board than to give it free rein. It is rather to adjudicate as between the parties by applying the law to the particular situation without fear or favor, and accordingly to grant enforcement to the Board or relief to the company.

This, moreover, is typical of the duty of every court in every case brought before it, irrespective of all differences in detail.

This responsibility of the courts as independent third parties is a crucial feature of a regime of law. It is admittedly such in the criminal and private law. Administrative law being taken to embrace all parts of the law which govern the relations between administrative agencies and private persons or organizations, it is presently 
pertinent to sum up the principal reasons why it is such in this area also.

\section{A Feature of the Constitutional SySTEM}

Judicial review of administrative action is a time-honored feature of our constitutional system. Hence, the importance of continuity with the past as a starting point of orderly improvement establishes a presumption in favor of continuance of the institution. Such review is, moreover, in one form or another, a feature of the constitutional systems of the leading Western nations. Hence, the fact that it is the product of a commonly felt need among countries blessed with popular government and the reign of law strongly reinforces the presumption.

In affirmative support of the presumption, the rationale of the institution is as applicable today as it was in simpler times. Indeed, it is underlined by the administrative expansion of the last two decades. For it affirms that the settlement by a court as an independent third party of a dispute between a private party and an administrative agency is called for in the public interest.

On the one hand, administrators are invested with authority over persons and property; and human beings so invested are apt, whether from overzealous devotion to their task or from less worthy motives, to exceed or abuse their lawful powers. Protection of private interests against such excess or abuse is an indispensable factor in any civilized conception of the public interest. For such protection, however, it is not enough that the law define the scope of such powers and prescribe that they be exercised reasonably in respect alike to substance and to method. It is essential that enforcement of the law be in the hands of the courts as independent third parties.
On the other hand, administrative powers over persons and property are necessary means to reasonable statutory ends of so limiting private freedom as to safeguard vital interests of the community as a whole. If, therefore, the exercise of these powers is found by the courts to be in content and procedure within the law, the public interest requires that the administrative determinations be sanctioned by coercive judicial decrees quite as clearly as in the contrary event it requires that the private interests concerned be protected.

Whichever way the courts decide, moreover, the result obtains from the fact that it is produced by an independent third party a powerful moral sanction. Not least when the stakes are high, this moral sanction is promotive of orderly government, for it greatly facilitates compliance on the part of the losing party and acquiescence on the part of those interests in society which are disappointed at the outcome.

To such reasoning the objection may be raised that the supposed regime of law is illusory, since the law is what the judges say it is, and hence that it is indefensible to vest in men who are not politically responsible the authority in their final discretion to restrict the exercise by administrative commissions of economic controls authorized by representative legislatures.

It is now generally recognized, to be sure, that the courts are far from being mere automatons, mere passive mouthpieces of a pre-existing law which is always unmistakable in its general terms and perfectly clear in its bearing upon all possible situations. This is not to deny that in many parts of the law there is a substantial core of certainty in the application of the law to run-ofthe-mine situations. It is to affirm, however, that throughout the law many hypothetical situations can be stated, and actual situations are constantly 
arising, to which the application of the law is uncertain, and will remain so until the court of last resort shall have spoken. It is further to affirm that notably in the dynamic field of administrative law there are whole areas of confusion.

Nor is that all. It is the precedents of the courts which have made the common law and equity what they are; and while the courts, in interpreting the written law, are limited by the language used, they fix the meaning of that language for all cases except those which patently come within its intent.

\section{The Supreme Court}

Now it may be that the degree of uncertainty in the law is exaggerated by centering attention upon courts of last resort; for theirs is the task of resolving legal uncertainties. This is especially true of the Supreme Court of the United States, to which appeal of right can be taken only in limited classes of cases, and which otherwise selects, by granting or denying petitions for certiorari, the cases which raise new or doubtful questions of law it deems it important to pass upon. Small wonder, then, that this court is often divided.

It is further to be noted in passing that, while a Supreme Court decision which makes new law is retroactive with respect to the given situation, it increases the certainty of the law for the future-a result which is in itself advantageous for all concerned-and that, however wrongheaded such a decision may seem to some informed critics, it is at least a reasoned decision which at the worst overemphasizes principles which judges and other men have long cherished.

In the last analysis, of course, the answer to the objection which has been raised must be that in administrative law, as in the criminal and private law, the independent third-party role of the courts is too precious to be abandoned even though it involves the fallible judgment of men. If those men are now thought to have "liberal" predilections, the predilections of their predecessors were as consistently "conservative."

\section{Alternative to Judicial Review}

The best defense of this role of the courts is to contemplate the alternative. In administrative law that alternative would be to allow administrators to determine, subject to political controls, their own powers. Such political controls are new legislation, Presidential direction, and political pressure. New legislation would depend upon the contingencies of politics and the delays of legislative procedure and, once enacted, would have the meaning given it by those it was designed to limit. Presidential direction does not presently apply to several administrative tribunals for the significant reason that, their duties being so analogous to those of courts as to be considered quasi-judicial and their orders being subject to only limited judjcial review, Congress has made them plural bodies whose members have overlapping terms and may not be removed by the President because he disagrees with their decisions. So vast has the national bureaucracy become that, even in relation to those agencies which are directly responsible to the President, his span of control stretches very thin; while, in any case. Presidential direction is by nature primarily political rather than remedial. It is notorious that political pressure from Senators and party chiefs spells favoritism rather than the insurance of impartiality. Political control would thus offer no specific or adequate protection to private interests against administrative orders, and might actually cause or aggravate administrative abuses. With administrative authority otherwise unrestrained, two great evils would be 
likely to arise. On the one hand, offcial decisions which were not liable to challenge before an independent third party would lack respect, receive at best reluctant compliance, and of ten be evaded through political influence and with a clear conscience. On the other hand, removal of the possibility of such challenge would be removal of restraints which that possibility now makes wholesomely operative.

\section{Broader Issues}

The objection which has been under examination raises still broader issues when applied to the bearing upon administrative law of a feature of our constitutional system which does not exist in England or France: judicial review of statutes. Our courts may hold an administrative determination invalid not only because it is unauthorized by the governing statute, but also because that statute is itself unconstitutional. This unconstitutionality may of course relate as well to the administrative as to the other provisions of the statute. In order, moreover, to avoid a constitutional issue, the courts may give an exceedingly narrow interpretation of statutory administrative powers. It is thus not possible for American legislatures, as it is for the British Parliament, to define the scope and methods of administrative action, and to narrow or eliminate judicial review thereof, without these enactments being subject to invalidation at the hands of the courts.

Opposition to judicial review of statutes centers upon a ground which has no special reference to administrative law. From democracy conceived as an absolute dogma, and from a formalistic identification with democracy of whatever representative institutions bring forth, there is deduced the conclusion that every enactment of such institutions must be given the force of law.
The subject is too large for treatment in this place; but a few remarks may be ventured, with administrative law especially in mind. The first premise of civilized government is the sacredness of every human personality as having been in some sense made in the image of God. From the conclusion that in the long run government is more apt to conform with this premise if conflicts of interest are resolved only with the consent of a representative assembly chosen by universal suffrage in free elections and with free discussion, rather than by any sort of traditional or self-appointed elite, it by no means follows that the authority to govern, even with the consent of such an assembly, is in any civilized society unlimited.

Government is civilized only if the resolution of conflicts of interest is limited by recognition that all men and all groups and lawful organizations of men have mutual interests in the basic civil liberties, in procedural and substantive fair play for all, and in having disputes arising out of particular situations adjudicated by an independent third party.

Recognition of these limits may of course be provided in more than one manner. It may be so firmly embedded in the habitual moral convictions of a people that the resulting moral restraints are on the whole adequate. If it is not to some extent so embedded, it cannot be secured by any purely artificial means.

\section{American AtTitudes}

We Americans stand somewhere between these extremes. The essential restraints have high authority from our past to support them; and there are courageous men in every generation to appeal to that authority. But we also have habits of irresponsibility which enable the passions of the moment to over- 
ride civilized restraints. It is probably well, therefore, that the constitutional limitation of due process, or fair play, is embodied, as obligatory even upon representative assemblies, in the fundamental law of the nation, and hence is to be applied as law when a court sits as an independent third party to settle a dispute between an administrator who relies upon a statutory provision and a private party who claims that that provision authorizes a denial of fair play.

Similarly, if judicial review of administrative action is a sine qua non of civilized government, should the supreme law of the land not ensure that the independent third party shall have untrammeled authority to exercise it? And how can it ensure this unless it gives that independent third party the last word on the scope of review which constitutionally must be allowed by statute?

\section{The Role of Criticism}

To justify judicial review in principle is not, however, to place it beyond criticism. General principles do not decide borderline cases. The choices which the Supreme Court is constantly making are choices of statesmanship, and judicial statesmanship, like political statesmanship, can falter and fail.

The suggestion may be hazarded that, aside from its deplorable stand in the matter of utility rate-making by administrative commissions, the old Court's most grievous failure, which justly brought judicial review into disrepute and almost inevitably led to the crisis of 1937, concerned administrative law less than such subjects as freedom of contract and dual federalism.

The new Court has corrected those errors, whether or not by going too far it is not possible here to inquire. It has also upheld Congress in devolving upon administrative agencies pow- ers which, in the scope of their discretion, are in sum impressive, and to many alarming. Yet for the Court to refuse to sanction the vesting of such administrative powers, or so to control their exercise as to hamstring administrative action as a means to permissible statutory ends, would be to defeat with one hand policies it declared constitutional with the other. It would be to deny to Congress the "necessary and proper" means of carrying into execution its delegated powers. If our once individualistic democracy has been increasingly socialized, surely the devil is neither Congress nor the Court, but the industrial-technological revolution.

What has been said makes apparent the urgent importance of judges' of all grades being men of sensitive conscience and exceptional wisdom and of their having their minds and consciences advised by the most searching criticism of their work by philosophers as well as lawyers and dissenters from the bench, exponents of the humanities as well as social scientists. It is, however, always to be remembered of and by the critics that theirs too is a fallible human judgment.

Nor is it to be forgotten that judicial statesmanship is of a different order from political statesmanship. The criteria which the Supreme Court and its critics should consciously apply in administrative law are implicit in the rationale of judicial review of administrative action. It is the task of this independent third party to weigh in the scales of judgment conflicting ends which are always represented in the administrative law cases it decides by the parties at its bar. One of these ends is to have specific enforcement in individual cases of the statutory and constitutional limits of administrative powers. The other end is that the governing process be not rendered ineffective by undue judicial interference. 
To say this is not to furnish a formula for the ready-made solution of particular problems; but it is the first lesson of wisdom that all such supposed formulas are illusory. It is, in truth, but to state a dilemma; but it is the second lesson of wisdom that the problems of life always appear as dilemmas. Without this realization men are apt to seize one horn without even considering the other, and thus to doom themselves to one-sided judgment.

In conclusion, a word to the layman. Were examination of administration and the courts now to proceed from the realm of generality to such specific questions as the methods, scope, and timing of judicial review, he would doubtless be surprised by two things. One would be, how many are the forms which the indicated dilemma in fact takes; and the other would be, how difficult the choices often become for anybody who does not focus his attention upon one of the competing ends to the exclusion of the other. The judicial task of maintaining a balance by sustaining administrators here and restraining them there is one of the highest that can be assigned to mortal men.

James Hart, Ph.D., after teaching at the University of Michigan and the Johns Hopkins University, has been since 1936 professor of political science at the University of Virginia. He was a member of the staff of the President's Committee on Administrative Management. His publications include An Introduction to Administrative Law with Selected Cases (1940; second edition 1950). 